\title{
The determinants of the business performance of commercial banks: A case study of Vietnam
}

\author{
Bui Thi Thu Loan \\ Hanoi University of Industry \\ loanbtt@haui.edu.vn \\ Vu Duy Hao \\ National Economic University \\ haovd@neu.edu.vn
}

\author{
Nguyen Xuan Thang \\ National Economic University \\ thangnx@neu.edu.vn \\ Ta Quang Hieu \\ National Economic University \\ Taquanghieu189@gmail.com
}

\begin{abstract}
The paper studies the factors affecting the business performance of commercial banks (2008 - 2018), based on the examination of bank characteristics according to the information on the financial statements of 24 commercial banks and macroeconomic factors. Our findings provide evidence on the significant influence of the factors of diversity on income structure, cost management and capital structure on the business performance of commercial banks. Some implications and future research directions are thereby proposed.
\end{abstract}

Index Terms-Capital structure, performance, diversity, bank.

\section{INTRODUCTION}

$\mathrm{B}$ USINESS performance is always a topic that receives the attention of researchers and managers. With different approaches, a vast body of literature has been put together to study the factors affecting business performance, thereby providing policy implications for business activities. However, due to the specificity of the field of operation, commercial banks are more easily affected by the problem of asymmetric information, adverse selection and moral hazard. Besides, the impact of macroeconomic factors is also considered to have more influence on the business activities of commercial banks than non-financial enterprises, given that other factors remain unchanged.

Therefore, although bank activities also aim at adding value for shareholders, including profitability goals similar to non-financial enterprises, the factors impacting the performance can be significantly different from those of non-financial firms. On the basis of these arguments, there are also many studies that have examined the factors affecting the business performance of commercial banks [4], [2], [13], [6]. However, existing research focuses mainly on countries with developed economies rather than countries with transitional economic contexts such as Vietnam. In addition, existing studies have not reached a high consensus on the influencing factors as well as the degree of influence of each factor on the business performance of commercial banks. Based on these considerations, the question arises in the context of Vietnamese enterprises, about how internal factors and macroeconomic factors affect the business performance of banks, as the information needing examination in order to enrich the knowledge on this issue is still quite scarce in Vietnam. The study also provides some implications for banking business management.

\section{Literature Review And Hypotheses}

Capital structure: Most of the profits that banks obtain are mainly from credit activities through the "borrowing to lend" function of commercial banks, although commercial banks must comply with regulations on legal capital to be able to operate. The equity component of commercial banks, therefore, is generally very large, compared to other non- financial enterprises. However, capital mobilized from deposit is the main source of raw materials for banks to use lending to earn profits. Therefore, when examining the model of factors affecting business performance of banks, the indicator of structure is a factor used consistently in the most existing research [5], [4], [15]. In Vietnam, over $70 \%$ of commercial banks' income comes from credit activities, and in some others, this rate is up to $90 \%$. Therefore, we hypothesize that capital structure has a positive effect on the financial performance of commercial banks.

Credit risk: Credit risk is one of the types of risks banks face that directly impact a bank's profitability. Although the study of Rasiah [16] suggested that it did not find empirical evidence on the impact of credit risk on bank performance, most studies support the view that changes in credit risk lead to changes in bank profitability [16]. Credit risk includes default risk and risk from unexpected events. When these adverse events occur (in whole or in part), they all cause partial or complete loss of principal or interest. As a result, the bank's profit will decline due to the increase in provisioning costs for each group of overdue debts and provision for handling when losses actually occur. For this reason, we expect the relationship between credit risk and profitability of commercial banks to be negative.

Liquidity risk: Liquidity risk is considered an intrinsic factor of the bank, where the bank might not be able to fulfill its payment obligation when it is due or be forced to pay high costs to fulfill the obligation in that case. This situation occurs when the bank is in a state of not being able to raise enough cash to support qualified loans as well as meet customers' centralized withdrawal needs at a certain time. The liquidity is measured through the ratio of outstanding credit to total deposits of the bank [3], [13]. The relationship between liquidity risk and profitability remains unclear. While some viewpoints support the opposite view, that the higher the liquid /deposit ratio, the lower the profit, with the argument that to re-establish the liquidity balance, the bank's 
costs will be higher, thus reducing profits. Our study also agrees with this view based on the argument that liquidity risk is an internal problem. Commercial banks will not be able to mobilize large deposits if they face liquidity risk, and credit size depends on deposit size. Therefore, we expect this relationship to be negative.

Cost management: Business activities in general and financial institutions in particular, costs are a component that is directly related to profitability. Effective cost management will bring higher profitability and vice versa. Empirical studies consistently support a positive relationship between these two factors [6]. Therefore, we hypothesize a negative relationship between cost ratio and the profitability of commercial banks.

Diversification: Some studies [9], [8] provide evidence of a negative relationship between non-interest income sources in the bank's income structure and profitability. However, it can be seen in theory that revenue from many different sources will bring the ability to improve profits by diversifying the business portfolio, while creating sustainability in the long term. Explaining this problem, it can be seen that although the income of banks comes mainly from credit activities, ceteris paribus, banks that obtain their income from many different sources will have higher revenue, and higher profits, increasing business performance. Non-interest income, in addition to creating sustainability for revenue sources, helps to bring about opportunities to increase income from diversification activities. Tunay and Silpar [17] has provided evidence of the positive influence of diversity on income structure for the profitability of commercial banks. Therefore, in this study, we suggest that income structure diversity has a positive effect on profitability.

Macroeconomic factors: The business performance of financial institutions is directly affected by changes in macroeconomic indicators of the economy, such as inflation or GDP growth. Inherently, in economic conditions that allow economic growth, and inflation to be controlled, entities within the economy will expand the scale of production and business activities as well as promote transactions related to the operation of financial institutions and vice versa. Naceur and Kandil [12] shows that inflation increases the uncertainty of economic activities, leading to a decrease in credit scale, thus decreasing the profitability of commercial banks. Additionally, an increase in GDP is an indicator of the ability to increase profitability [1]. Therefore, we propose a negative relationship between inflation and profitability and a positive relationship between GDP growth and profitability of banks.

Aside from the factors mentioned above, the scale of operation of commercial banks is also one controlled by most studies in quantitative models [13], [14], [18] based on the argument that banks with larger size possess less risk (more credible) can make more profits through lending from obtaining more deposits, thus achieve higher profitability and performance, ceteris paribus. On that basis, and based on the argument of scale advantage, our research proposes a positive relationship between bank size and business performance.

\section{Methodology}

\section{A. Variables and variable measurement}

To examine the hypotheses proposed above, the independent and dependent variables are measured according to the scales detailed in the table below, in which business performance is measured according to 2 indicators, including ROA and ROE. The independent variables are also measured based on relevant business characteristics information for each measurement criterion.

TABLE 1

VARIABLE DESCRIPTION

\begin{tabular}{|l|l|l|}
\hline Variables & Description & Measurement \\
\hline \multirow{2}{*}{ FP } & $\begin{array}{l}\text { Financial performance is } \\
\text { measured by ROA and } \\
\text { ROE }\end{array}$ & ROA= Profit / Total Assets \\
\cline { 3 - 3 } CS & $\begin{array}{l}\text { Capital Structure of bank i } \\
\text { in year t }\end{array}$ & ROE= Profit / Total Equity \\
\hline C_RISK & $\begin{array}{l}\text { Credit risk of bank i in } \\
\text { year t }\end{array}$ & $\begin{array}{l}\text { Provision for loan losses/ } \\
\text { Outstanding Loans }\end{array}$ \\
\hline DIVERT & $\begin{array}{l}\text { Diversity of income } \\
\text { structure of bank }\end{array}$ & $\begin{array}{l}\text { Non-interest income/ Total } \\
\text { Assets }\end{array}$ \\
\hline LIQRISK & Liquidity risk of bank & Liquid Assets / Total Assets \\
\hline EXP & $\begin{array}{l}\text { Expense management of } \\
\text { bank }\end{array}$ & $\begin{array}{l}\text { Operating Expenses / Total } \\
\text { Assets }\end{array}$ \\
\hline SIZE & Size of bank i in year t & Ln(Total Asset) \\
\hline INF & Inflation in year t & (CPIt - CPIt-1) / CPIt-1 \\
\hline GDP & Gross domestic product & (GDPt-GDPt-1)/GDPt-1 \\
\hline Eit & Error term & \\
\hline
\end{tabular}

\section{B. Research model, sample and data}

To test the research hypotheses, the research model for the variables measured according to the scale as presented in Table 1 above is as follows:

$\mathrm{FPi}, \mathrm{t}=\beta_{0}+\beta_{1} \mathrm{CSi}, \mathrm{t}+\beta_{2} \mathrm{CRISK}+\beta_{3}$ LIQRISK $+\beta_{4} \mathrm{EXP}+$ $\beta_{5}$ DIVERT $+\beta_{6}$ SIZE $+\beta_{7}$ INF $+\beta_{8}$ GDP $+\varepsilon i, t$

The initial final analysis sample of banks with 240 observations.

\section{Results}

\section{- Descriptive statistical analysis}

On average, ROA and ROE of commercial banks in the sample are about $0.8 \%$ and $8.4 \%$, respectively. Some banks have reported losses during this period, which is statistically shown by the smallest values of this variable. The detailed data are presented in Table 1. In addition, these statistical values also show that during the research period, the research sample included observations with loss in credit activities as well as in non-interest income, as shown by the negative value of the variable income structure and credit risk.

TABLE 2: VARIABLE DESCRIPTION

\begin{tabular}{|l|r|r|r|r|}
\hline Variables & \multicolumn{1}{c|}{ Mean } & Minimum & Maximum & \multicolumn{1}{c|}{ Std. Deviation } \\
\hline ROA & 0.007 & -0.055 & 0.047 & 0.007 \\
\hline ROE & 0.084 & -0.082 & 0.268 & 0.081 \\
\hline SIZE & 25.102 & 21.926 & 27.903 & 1.149 \\
\hline CS & 0.099 & 0.035 & 0.332 & 0.046 \\
\hline CRISK & -1.50197 & -86.903 & -0.002 & 7.906 \\
\hline DIVERT & 0.025 & -0.006 & 0.090 & 0.011 \\
\hline LIQRISK & 0.073 & 0.013 & 0.368 & 0.055 \\
\hline EXP & 0.0162 & 0.004 & 0.052 & 0.005 \\
\hline
\end{tabular}




\section{- Regression analysis}

The Hausman test favors group analysis data under the fixed effects model. The necessary tests of the regression model including multicollinearity and autocorrelation are also performed and corrected based on the robust option. The results of the analysis of factors affecting the financial performance of commercial banks are shown in Table 4 below.

The analysis results show that the factors of capital structure, non-interest income, cost management and inflation have an influence on the financial performance of commercial banks on the data of the research sample for the ROA scale, in which the influence of cost management factors, capital structure and diversity in the bank's income sources impact most significantly. The degree of influence of these factors on the profitability of assets are $-1.04 ; 0.08$ and 0.52 respectively at $5 \%$ significance level. The effect of the inflation rate on the ROA scale is insignificant and does not support the direction of the research hypothesis. We also do not find supporting evidence on the impact of risk factors including credit risk, liquidity risk and bank size on the business performance of the banks in this study being at 5\% significance.

Regarding testing the data on the ROE scale, the results are generally in agreement when compared with the ROA scale, except that this model further confirms the influence of liquidity risk on the business performance of banks with relatively high influence $(-0.29)$ at $5 \%$ significance level.

TABLE 3

REGRESSION ANALYSIS RESULTS OF FACTORS AFFECTING ROA

\begin{tabular}{|r|c|c|c|c|c|c|}
\hline \multicolumn{1}{|c|}{ ROA } & $\begin{array}{c}\text { Coeffi- } \\
\text { cient }\end{array}$ & $\begin{array}{c}\text { Std. } \\
\text { Err. }\end{array}$ & $\mathbf{t}$ & $\mathbf{P}>|\mathbf{t}|$ & \multicolumn{2}{|c|}{$\begin{array}{c}\text { [95\% Conf. } \\
\text { Interval] }\end{array}$} \\
\hline CS & 0.081 & 0.014 & 5.79 & 0.000 & 0.05 & 0.108 \\
DIVERT & 0.527 & 0.044 & 11.89 & 0.000 & 0.44 & 0.614 \\
LIQRISK & -0.017 & 0.0097 & -1.72 & 0.086 & -0.03 & 0.002 \\
EXP & -1.044 & 0.0781 & -13.35 & 0.000 & -1.19 & -0.890 \\
CRISK & 0.0001 & 0.0004 & 1.63 & 0.104 & -0.00 & 0.000 \\
SIZE & -0.00 & 0.00 & -1.36 & 0.176 & -0.00 & 0.001 \\
INF & 0.0007 & 0.0003 & 2.33 & 0.021 & 0.00 & 0.001 \\
GDP & 0.0005 & 0.0005 & 0.95 & 0.344 & -0.00 & 0.002 \\
cons & 0.038 & 0.0274 & 1.39 & 0.165 & -0.03 & 0.092 \\
\hline
\end{tabular}

\section{Discussion and Future Research Directions}

Research results on the factors affecting the business performance of commercial banks confirm the hypotheses on the influence of capital structure, income structure, cost management and inflation, in which the influence of inflation is insignificant. These results have been supported by previous studies; for example, the effect of capital structure on bank performance is confirmed in the study of [5], [13]. In Vietnam, equity size is also an important parameter related to the credit growth of commercial banks, so this result is meaningful for commercial banks for strategic planning in the capital increase roadmap.

The effect of income structure confirmed in this study is consistent with the results of Tunay or Baele [17], This result emphasizes the role of investment strategy and avoids only dependence on income from credit activities. This is a remarkable point for the business activities of commercial banks in Vietnam at present. Additionally, in order to increase business efficiency, cost management is also a factor that banks need to pay attention to. This problem requires banks to design a more reasonable cost structure when compared with industry averages.

Although our study achieved certain results, we acknowledge that the study has certain limitations. In the period of 2018 - 2020, the economic context has significantly changed due to the impact of the Covid-19 pandemic and the shifting trend of the banking industry. However, these data have not been updated and analysed in the sample. The potential of endogeneity in the panel data model has also not been examined. This is also the direction of future research that needs to be done in order to draw more complete conclusions about the research results of factors affecting the business performance of commercial banks in Vietnam.

\section{REFERENCES}

[1]. Athanasoglou, P., Brissimis, S., \& Delis, M. (2008). Bank-specific, industry-specific and macroeconomic determinants of bank profitability. Journal of International Financial Markets, Institutions \& Money. 18, pp.121-136.

[2]. Athanasoglou, P., Delis, M. \& Staikouras, C. (2006) Determinants of Bank Profitability in the Southern Eastern European Region. Bank of Greece Working Paper. 47.

[3]. Berríos. MR, (2013). The relationship between bank credit risk and profitability and liquidity. The International Journal of Business and Finance Vol 7. Pp $105-118$.

[4]. Berger, A.L. (1995) The Relationship between Capital and Earnings in Banking. Journal of Money, Credit and Banking, 272), pp.432-456.

[5] Berger, A.L. Patti. EB (2006) Capital structure and firm performance: A new approach to testing agency theory and an application to the banking industry. Journal of Banking \& Finance.

[6]. Dietrich, A. and Wanzenried, G. (2011). Determinants of bank profitability before and during the crisis: Evidence from Switzerland. Journal of International Financial Markets, Institutions and Money, 21(3), pp.307-327.

[7]. Eichengreen, B. and Gibson, H. (2001) Greek Banking at the Dawn of the New Millennium. CEPR Discussion Paper, No. 2791.

[8]. Elsas, R., Hackethal, A. and Holzhäuser, M. (2008). The Anatomy of Bank Diversification. SSRN Electronic Journal, 34(6), pp.1274-1287.

[9].Goddard, J., McKillop, D. and Wilson, J. (2008). The Diversification and Financial Performance of US Credit Unions. Journal of Banking \& Finance, 32(9), pp.1836-1849.

[10]. Hausman, J. A. (1978). Specification tests in econometrics. Econometrica 46: 1251-1271.

[11].Molyneux, P., Thornton, J. (1992). Determinants of European bank profitability: a note.

[12].Naceur, S.B. \& Kandil, M. (2009) The impact of capital requirements on banks' cost of intermediation and performance: The case of Egypt. Journal of Business and Economics. 61(1), pp.70-89.

[13].Pasiouras, F. and Kosmidou, K. (2007), "Factors influencing the profitability of domestic and foreign banks in the European Union", Research in International Business and Finance, 21(2), pp. 222-237.

[14] Perera, S., Skully, M., \& Wickramanayake, J. (2007). Cost efficiency in South Asian banking: the impact of bank size, state ownership and stock exchange

[15].Pratomo, Ario. W, Ghafar (2006). Islamic bank performance and capital structure. MPRA Paper No. 6012, MPRA Paper No. 6012, posted 29 Nov 2007

[16] Rasiah, D. (2010). Theoretical Framework of Profitability as Applied to Commercial Banks in Malaysia. European Journal of Economics, Finance and Administrative Services.19, pp.74-97.

[17].Tunay, K.B., Silpar, M.A., 2006. Performance Analysis Based on Profitability in Turkish Banking Sector. Banks Association of Turkey, Research Papers, No: 2006-I.

[18].Zhao, S.Y \& Zhao, S.F (2013) States Ownership, Size and Bank profitability: Evidence from Chinese Commercial Banks, 19982011.Information Technology Journal. 12 (16). 